\title{
Chemical characters of crater lakes in the Azores and Italy: the anomaly of Lake Albano
}

\author{
Marino Martini, ${ }^{1}$ Luciano Giannini, ${ }^{1}$ Franco Prati, ${ }^{1}$ Franco Tassi, ${ }^{1}$ \\ BRUNO CAPACCIONI ${ }^{2}$ and PAOLO IOZZELLI ${ }^{3}$ \\ ${ }^{1}$ Department of Earth Sciences, University of Florence, 50121 Florence, Italy \\ ${ }^{2}$ Institute of Volcanology and Geochemistry, University of Urbino, 61029 Urbino, Italy \\ ${ }^{3}$ Department of Pharmaceutical Sciences, University of Florence, 50121 Florence, Italy
}

(Received April 23, 1993; Accepted January 10, 1994)

\begin{abstract}
Investigations have been carried out on crater lakes in areas of recent volcanism in the Azores and in Italy, with the aim of detecting possible evidence of residual anomalies associated with past volcanic activities; data from crater lakes of Cameroon have been considered for comparison. Among the physicalchemical characters taken into account, the increases of temperature, ammonium and dissolved carbon dioxide with depth are interpreted as providing information about the contribution of endogene fluids to the lake water budgets. The greater extent of such evidence at Lakes Monoun and Nyos (Cameroon) appears associated with the disasters that occurred there during the last decade; some similarities observed at Lake Albano (Italy) suggest a potential instability also for this crater lake.
\end{abstract}

\section{INTRODUCTION}

Crater lakes in active volcanic systems have been investigated with reference to changes occurring in water chemistry in response to different stages of activity, and interesting information is available about Ruapehu (Giggenbach, 1974), Kusatsu-Shirane (Ossaka et al., 1980), Chichòn (Casadevall et al., 1984), Poàs (Casertano et al., 1985), and Maly Semyachik (Fazllullin, pers. comm.). Much of the attention of scientists and public officials, however, has been recently captured by crater lakes not influenced by active volcanism; in fact, the events in Cameroon, at Lakes Monoun (Sigurdsson et al., 1987) and Nyos (Sigvaldason, 1989), represent the consequences of a rather uncommon type of geologic hazard. Crater lakes appear thus to deserve serious attention as potential sources of disasters significantly affecting the populations in the surrounding areas.

Systematic investigations of water chemistry have been carried out at crater lakes in areas of recent volcanism in Italy and in the Azores; other results from Cameroon have been used for com- parison. With reference to the data collected so far and considering the possibility that the actual chemical characters of crater lakes are influenced by residual thermal anomalies in the hosting volcanic systems, an effort has been made to verify whether and to what extent these anomalies can be revealed by simple observations.

$\mathrm{Be}$ this procedure sufficiently correct, monitoring a large number of crater lakes would become a viable program even where high-level technology is not available and a wealth of information could be easily collected. According to the intensity of thermal and chemical anomalies, possibly related to past volcanic activities, different levels of probability could be estimated for potentially hazardous events.

\section{Volcanological SETTINGS}

Given the general aim of this investigation, main attention was paid to the location of lakes within volcanic systems, and the difference between craters representing the whole structure or pertaining to larger calderas is not supposed to 


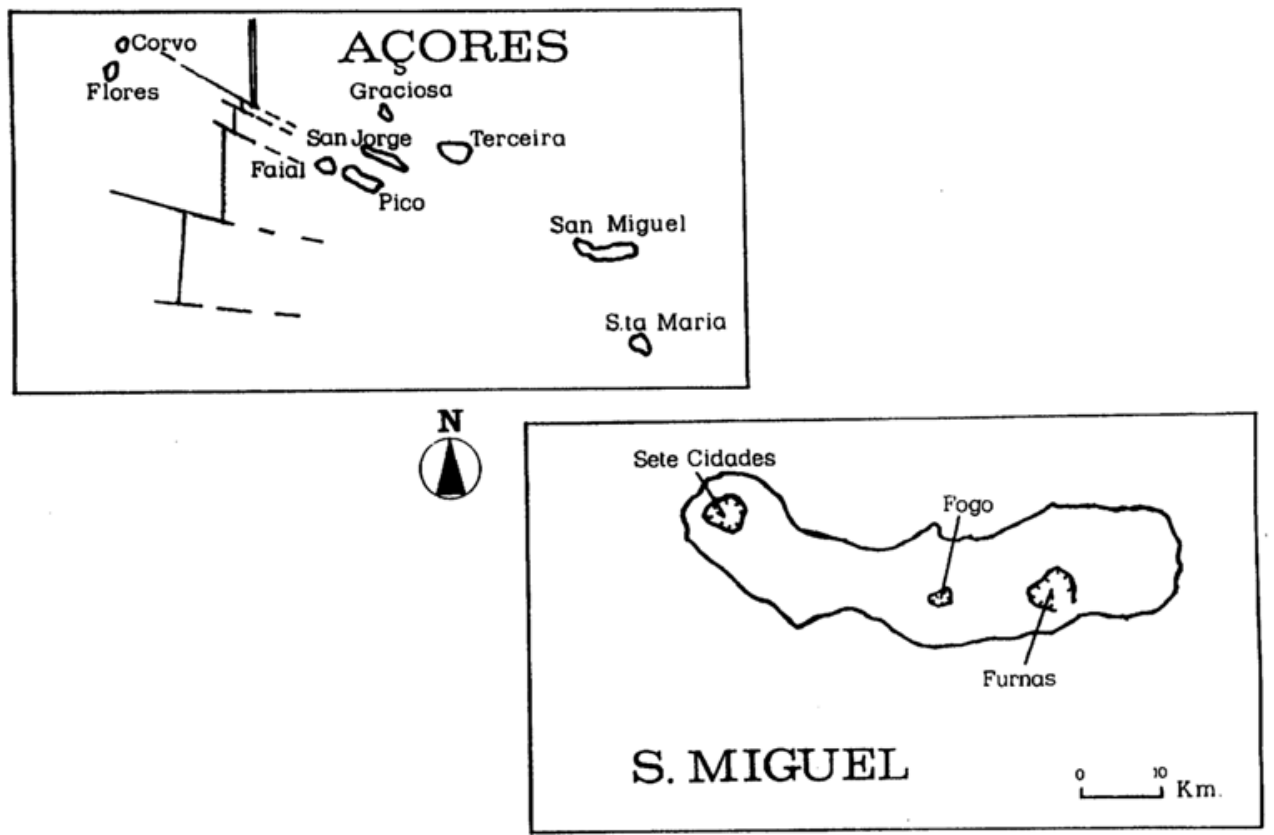

Fig. 1. Location of the crater lakes in the Azores.

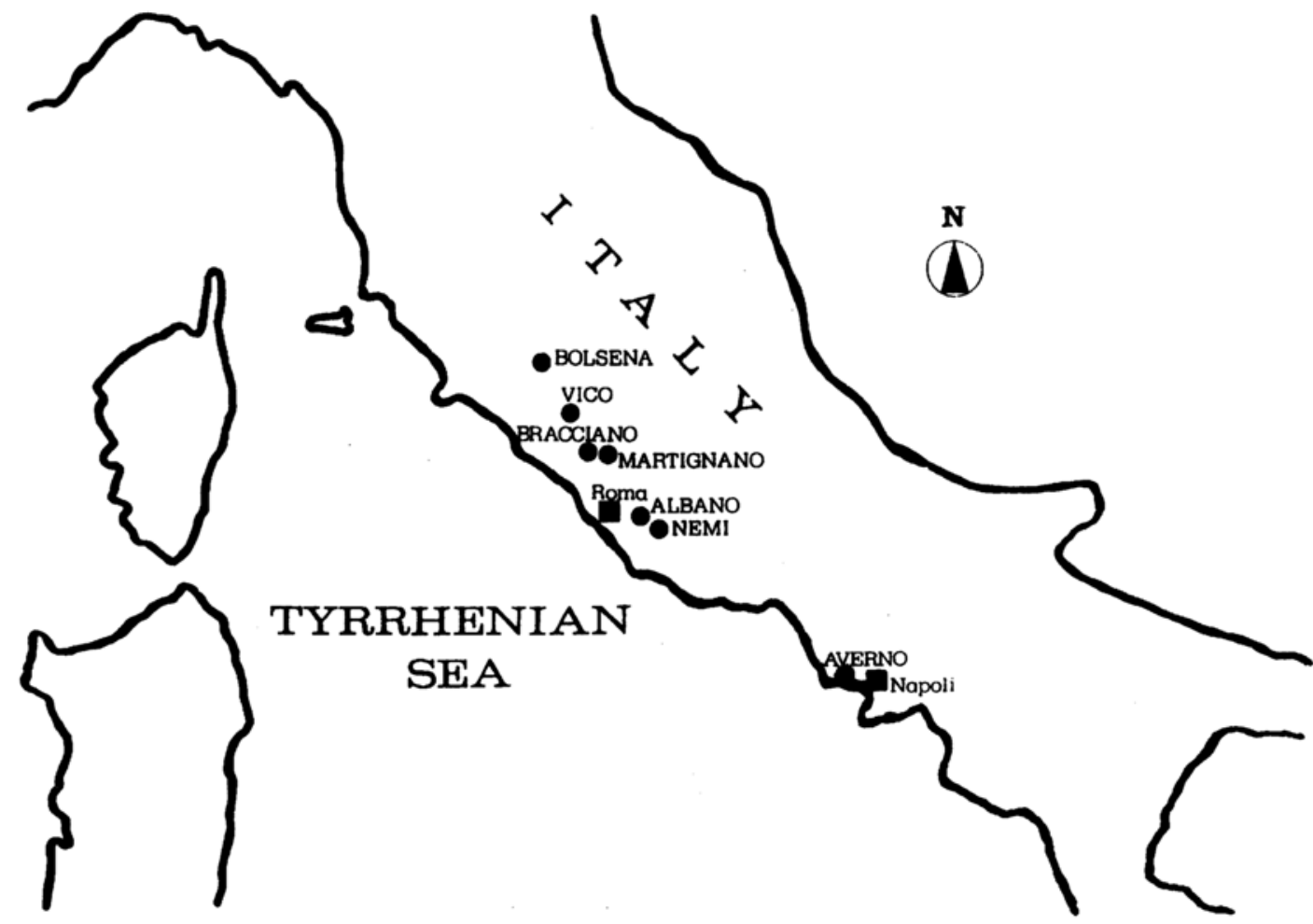

Fig. 2. Location of the crater lakes in Italy. 
affect to a significant extent the chemical characters under consideration.

Significant volcanic activity is reported for the Azores, crossed in a north-south direction by the axis of the Mid-Atlantic ridge (Fig. 1); besides the last surtseyan eruption of Capelinhos at Faial in 1957-58 (Machado et al., 1962), strombolian activity with lava flows occurred in 1761 at Terceira, and four explosive eruptions are recorded for S. Miguel in 1563, 1638, 1640, and 1811 (Booth et al., 1983). Fogo lake fills the summit depression of Agua de Pau volcano, about $3 \mathrm{~km}$ wide; its present morphology results from cratering, volcano-tectonic collapse, and landslides. Sete Cidades lake is located inside a polygenetic caldera, $5 \mathrm{~km}$ in diameter, produced during a long series of plinian events, the last probably occurred in 1444. Furnas lake occupies the summit of the easternmost active stratovolcano, truncated by a large polygenetic collapse caldera, about $6 \mathrm{~km}$ wide. A well documented historical eruption is reported in 1640; intense thermal activity is at present occurring inside the caldera.

With reference to Italian lakes (Fig. 2) Bolsena lake is a large volcano-tectonic depression, about $13 \mathrm{~km}$ in diameter, probably produced by a series of huge ignimbrite forming eruptions during the period 0.60-0.35 m.y. b.p. (Varekamp, 1980; Gillot et al., 1991). The volcanic activity continued in the western Vulsini area probably up to 0.125 m.y. ago, where the well shaped polygenetic Latera caldera developed (Nappi et al., 1991; Turbeville, 1993).

The activity of Vico volcano occurred from 0.40 to 0.09 m.y. b.p.; its summit appears as truncated by a polygenetic collapse caldera, about $8 \mathrm{~km}$ wide (Bertagnini and Sbrana, 1986), and half of the caldera floor is occupied by the lake, probably established after a giant ignimbritic eruption dated at about 0.15 m.y. (Locardi, 1965). Explosive paroxysmal eruption with subordinate effusive episodes characterized the Sabatini area during a period of 0.60 m.y., and the development of the volcano-tectonic depression of Bracciano lake followed the exhaustion of the eruptive activity about 40,000 years ago (De Rita, pers. comm.). Martignano lake pertains to the same structure. The activity of Alban Hills volcanic complex occurred during the period $0.70-0.036$ m.y. b.p. with hydromagmatic explosions from eccentric craters in its final phase; Nemi and Albano lakes are filling two of these craters (De Rita et al., 1991). Phlegrean Fields are located inside a large caldera possibly produced during a giant ignimbrite eruption about 0.035 m.y. ago (Rosi et al., 1983). The crater hosting Lake Averno is considered as a monogenetic tuff ring formed during the recent subaerial period; it is dated at about 3.800 y.b.p. The last eruptive event in the area occurred in 1538 with the build up of a 140 $\mathrm{m}$ high tuff cone.

\section{Sampling and Analytical Procedures}

Water sampling has been carried out along a vertical profile above the deepest point of lake bottom; the position of the boat was constantly checked by means of a portable GPS (Sony IPS360 ). Samples from depth have been collected in closed containers. Temperature was measured in situ, $\mathrm{pH}$ at the surface, at the same time of the collection of samples for dissolved $\mathrm{CO}_{2}$ determination, in $100 \mathrm{ml}$ glass bottles containing $10 \mathrm{ml}$ of a $1 \mathrm{M} \mathrm{Na}_{2} \mathrm{CO}_{3}$ solution. The $\mathrm{CO}_{3}{ }^{2-}$ excess subsequent to the reaction: $\mathrm{H}_{2} \mathrm{O}+\mathrm{CO}_{2}+\mathrm{CO}_{3}{ }^{2-}$ $\Rightarrow 2 \mathrm{HCO}_{3}{ }^{-}$allows then the calculation of dissolved $\mathrm{CO}_{2}$.

The analytical methods used are as follows. Anions and dissolved $\mathrm{CO}_{2} \Rightarrow$ Automatic titration with a Titroprocessor Metrohm 636 equipped with ion selective electrodes. Cations and Boron $\Rightarrow$ Ionchromatography with a Dionex DX100. $\mathrm{NH}_{4} \Rightarrow$ Potentiometric determination. $\mathrm{Li} \Rightarrow$ Atomic absorption spectrophotometry.

\section{ObSERVATION DATA AND Discussion}

The analytical results of major components for the samples collected from crater lakes at the surface and at approximately the maximum depth are given in Table 1.

Our attention has been mainly focussed on an- 


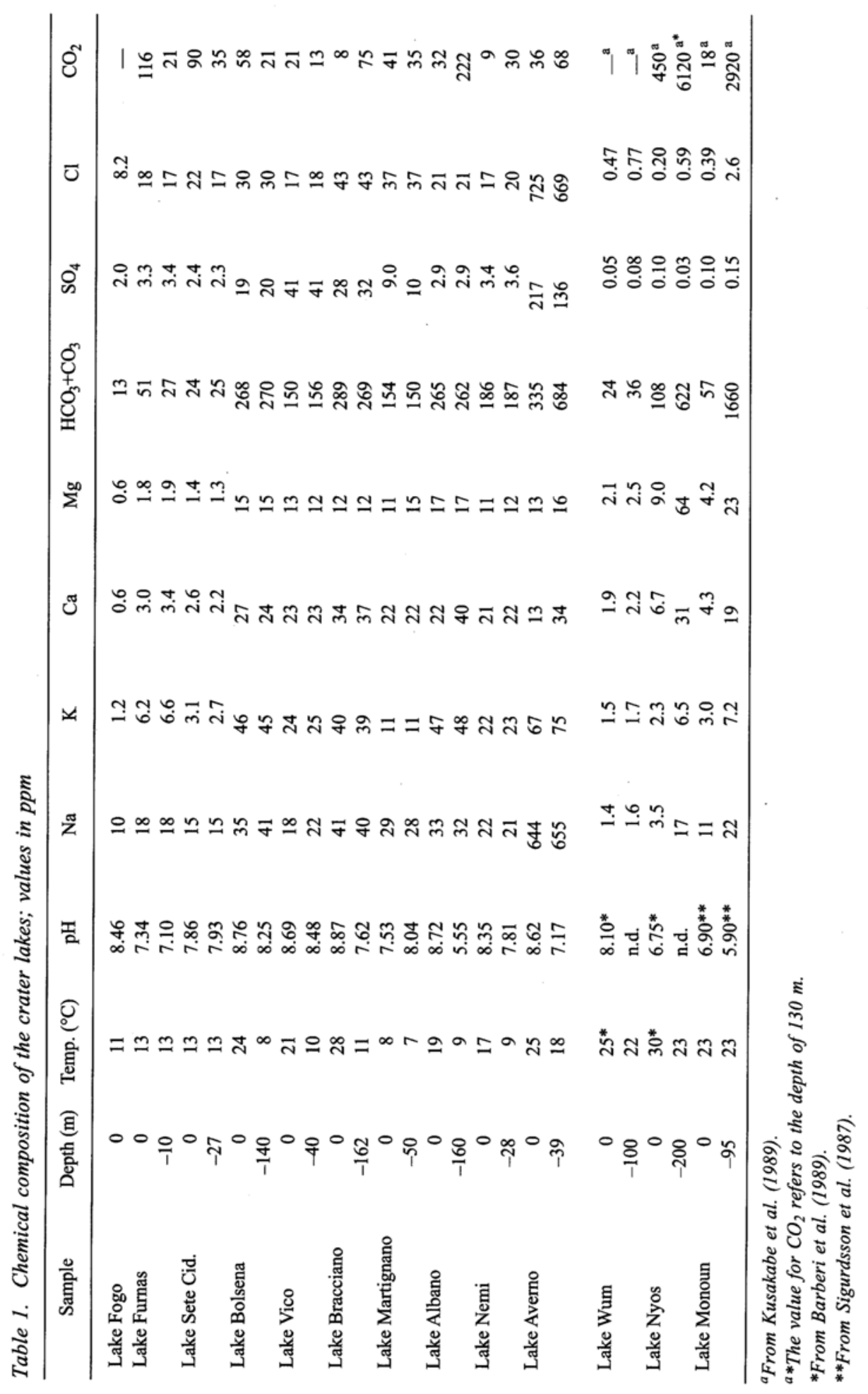


ions and $\mathrm{CO}_{2}$ distribution, which appear to provide the best information. Figure 3 allows us to observe, besides the minor contribution of sulfur species, a trend along a $\mathrm{Cl}-\mathrm{HCO}_{3}$ line, possibly resulting from varying extents of chloride or of carbon dioxide.

The contribution of marine spray to the chloride concentration can be important for the lakes located near coastlines (Fogo, Sete Cidades, Furnas, Averno), and $\mathrm{CO}_{2}$ inputs can be inferred for the lakes whose representative points lie near the bicarbonate corner; further information, however, can be obtained from the data of Table 2 .

The contribution of $\mathrm{CO}_{2}$ to natural solutions gives rise to a series of reactions, producing $\mathrm{HCO}_{3}$ or $\mathrm{CO}_{3}$ depending on $\mathrm{pH}$ conditions; these latter species represent the stable forms, unless a continuous input of $\mathrm{CO}_{2}$ takes place. Accordingly, the values of the ratio $\mathrm{CO}_{2} /\left(\mathrm{CO}_{3}+\mathrm{HCO}_{3}\right)$ can allow an estimation of the persisting importance of $\mathrm{CO}_{2}$ contributions. The discrepancies with respect to the theoretical balance between $\mathrm{pH}$ and distribu- tion of carbon species, observed in most of the samples investigated, appear to reconfirm a perturbed situation which does not allow the attainment of a physico-chemical equilibrium. Anomalous values of $\mathrm{CO}_{2}$ input can be derived for Nyos,

Table 2. Values of the ratio $\mathrm{CO}_{2} / \mathrm{HCO}_{3}+\mathrm{CO}_{3}$ for the samples from crater lakes (see text)

\begin{tabular}{llc}
\hline \multicolumn{1}{c}{ Sample } & \multicolumn{2}{c}{$\mathrm{CO}_{2} / \mathrm{HCO}_{3}+\mathrm{CO}_{3}$} \\
& Surface & Maximum depth \\
\hline Lake Furnas & 2.3 & 0.78 \\
Lake Sete Cidades & 2.7 & 1.4 \\
Lake Bolsena & 0.21 & 0.078 \\
Lake Vico & 0.14 & 0.083 \\
Lake Bracciano & 0.028 & 0.28 \\
Lake Martignano & 0.27 & 0.23 \\
Lake Albano & 0.12 & 0.85 \\
Lake Nemi & 0.048 & 0.16 \\
Lake Averno & 0.11 & 0.10 \\
& & \\
Lake Nyos & 4.2 & $13.6^{\mathrm{a}}$ \\
Lake Monoun & 0.31 & $1.8^{\mathrm{a}}$ \\
\hline
\end{tabular}

${ }^{a}$ From Kusakabe et al. (1989).

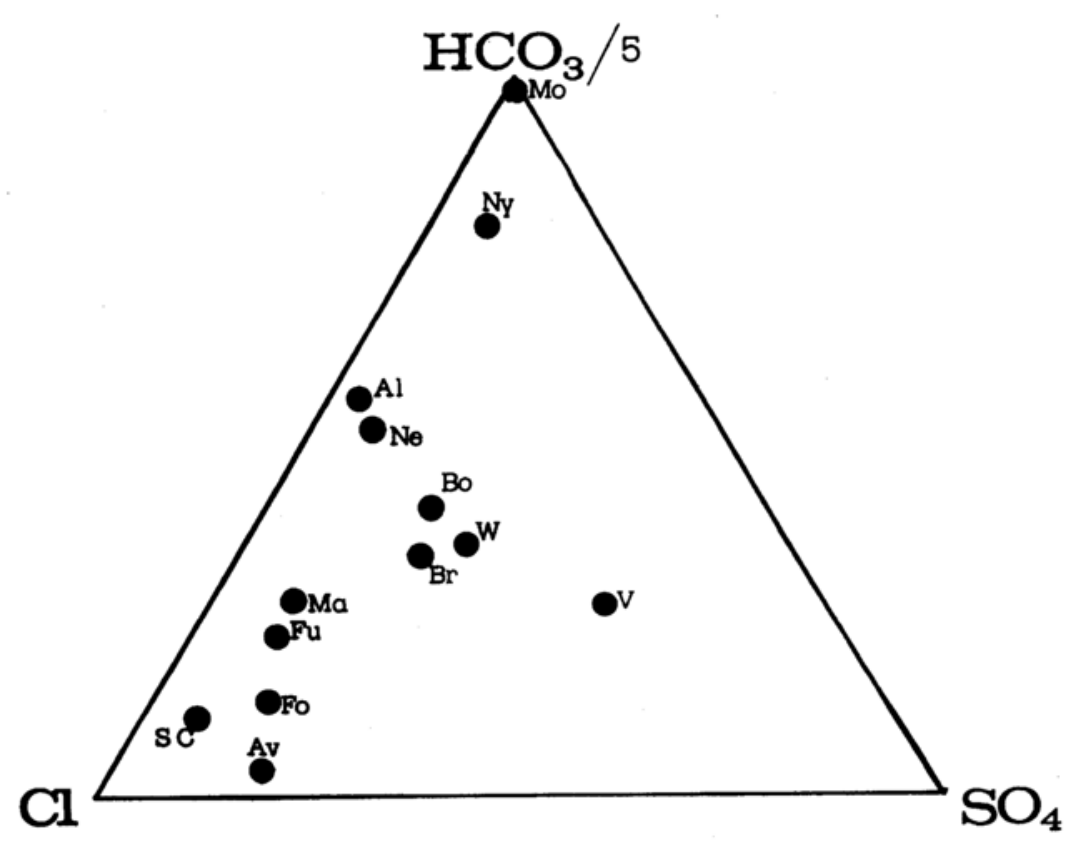

Fig. 3. Diagram $\mathrm{HCO}_{3}-\mathrm{Cl}-\mathrm{SO}_{4}$ for the samples from the surface of crater lakes. Mo (Monoun), $\mathrm{Ny}$ (Nyos), W (Wum), SC (Sete Cidades), Fo (Fogo), Fu (Furnas), Bo (Bolsena), V (Vico), Ne (Nemi), Br (Bracciano), Ma (Martignano), Al (Albano), Av (Averno). 
Monoun, Furnas, Sete Cidades, and Albano; at Furnas and Sete Cidades the main contribution appears to occur at or near the surface, while at Nyos, Monoun, and Albano, significant increases are observed at maximum depths.

The distributions of $\mathrm{NH}_{4}, \mathrm{~B}$, and $\mathrm{Li}$ in natural waters pertaining to volcanic systems appeared useful in investigating the contributions of different processes (Martini et al., 1984). Ammonia gas, giving rise to $\mathrm{NH}_{4}$ when dissolved in aqueous solutions, can migrate at relatively low temperatures; the migration of boron in natural environments is mainly associated to vapour phases, which require a significant extent of heat contribution; not negligible concentrations of lithium in natural solutions always derive from prolonged leaching of country rocks, enhanced by higher temperatures.
The ratios among the above mentioned components, accordingly, can be related to the prevailing processes operating in the areas, possibly associated to different extents of thermal anomalies.

According to this interpretation, the data reported in Table 3 and Fig. 4 can suggest a seepage of gases through substantially closed systems for Cameroon and the Azores, while thermal anomalies of greater extent appear to characterize most of the Italian lakes.

The significant differences in ammonium and dissolved carbon dioxide observed for samples collected at the surface or at maximum depth, however, seem especially to deserve further consideration. Natural contributions of ammonium to the environment derive largely from degradation of organic material, sometimes in association with

Table 3. Distribution of $\mathrm{NH}_{4}, \mathrm{Li}$ and $\mathrm{B}$ in the samples from crater lakes

\begin{tabular}{|c|c|c|c|c|}
\hline Sample & Depth (m) & $\mathrm{NH}_{4}$ & B & $\mathrm{Li}$ \\
\hline Lake Fogo & 0 & 0.32 & 0.010 & 0.002 \\
\hline \multirow[t]{2}{*}{ Lake Furnas } & 0 & 0.31 & 0.010 & 0.003 \\
\hline & -10 & 0.25 & 0.010 & 0.003 \\
\hline \multirow[t]{2}{*}{ Lake Sete Cidades } & 0 & 0.29 & 0.010 & 0.001 \\
\hline & -27 & 0.38 & 0.010 & 0.002 \\
\hline \multirow[t]{2}{*}{ Lake Bolsena } & 0 & 0.17 & 0.44 & 0.020 \\
\hline & -140 & 0.10 & 0.38 & 0.018 \\
\hline \multirow[t]{2}{*}{ Lake Vico } & 0 & 0.18 & 0.22 & 0.020 \\
\hline & -40 & 0.31 & 0.22 & 0.020 \\
\hline \multirow[t]{2}{*}{ Lake Bracciano } & 0 & 0.063 & 0.33 & 0.011 \\
\hline & -162 & 0.036 & 0.32 & 0.014 \\
\hline \multirow[t]{2}{*}{ Lake Martignano } & 0 & 0.14 & 0.001 & 0.001 \\
\hline & -50 & 0.16 & 0.001 & 0.001 \\
\hline \multirow[t]{2}{*}{ Lake Albano } & 0 & 0.014 & 0.55 & 0.001 \\
\hline & -160 & 0.31 & 0.22 & 0.001 \\
\hline \multirow[t]{2}{*}{ Lake Nemi } & 0 & 0.27 & 0.29 & 0.001 \\
\hline & -28 & 0.56 & 0.29 & 0.001 \\
\hline \multirow[t]{2}{*}{ Lake Averno } & 0 & 0.090 & 1.2 & 0.38 \\
\hline & -39 & 16 & 1.2 & 0.37 \\
\hline \multirow[t]{2}{*}{ Lake Wum } & 0 & 0.85 & 0.080 & $-^{\mathrm{a}}$ \\
\hline & -100 & 0.76 & n.d. & n.d. ${ }^{b}$ \\
\hline \multirow[t]{2}{*}{ Lake Nyos } & 0 & 2.5 & 0.044 & - $^{\mathrm{a}}$ \\
\hline & -200 & 7.9 & n.d. & n.d. ${ }^{b}$ \\
\hline \multirow[t]{2}{*}{ Lake Monoun } & 0 & 0.1 & n.d. & n.d. ${ }^{\mathrm{c}}$ \\
\hline & -90 & 12 & n.d. & n.d. ${ }^{\mathrm{c}}$ \\
\hline
\end{tabular}

${ }^{a}$ From Barberi et al. (1989).

${ }^{b}$ From Kusakabe et al. (1989).

${ }^{c}$ From Sigurdsson et al. (1987). 


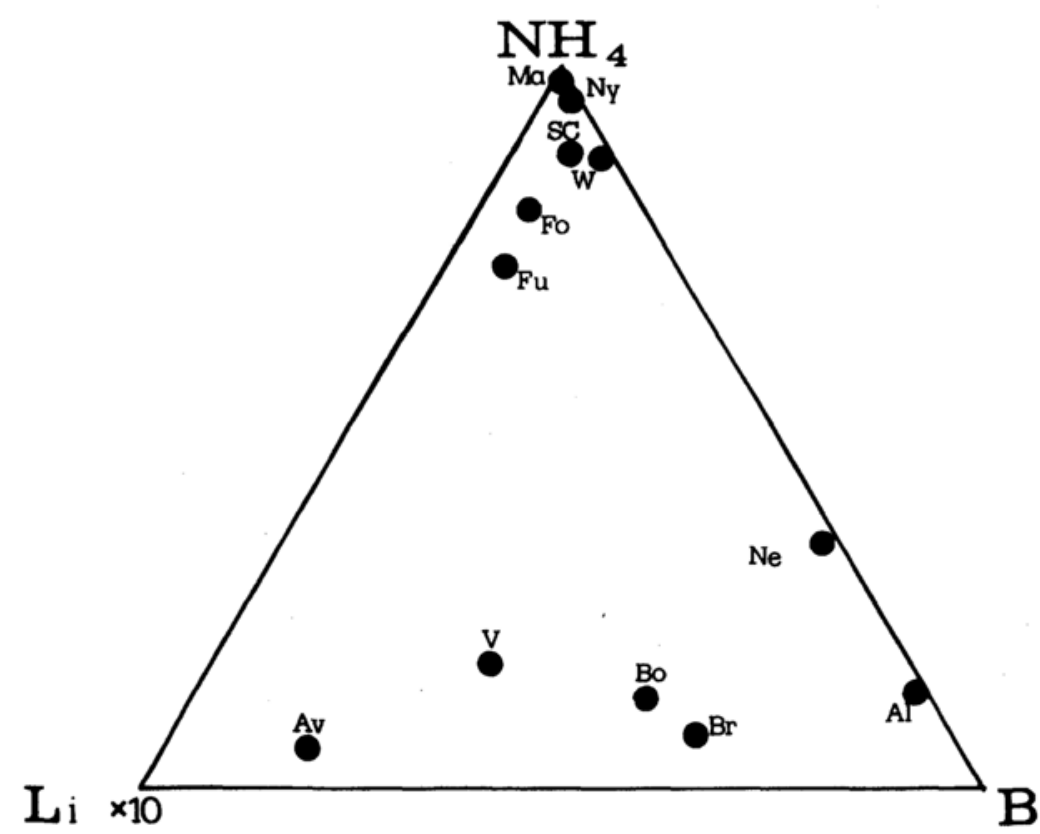

Fig. 4. Diagram $\mathrm{NH}_{4}-\mathrm{Li}-\mathrm{B}$ for the samples from the surface of crater lakes. $\mathrm{Ny}$ (Nyos), W (Wum), SC (Sete Cidades), Fo (Fogo), Fu (Furnas), Bo (Bolsena), V (Vico), Br (Bracciano), Ma (Martignano), Al (Albano), Ne (Nemi), Av (Averno).

important thermal anomalies; leakage of ammonium is in fact an effective indicator of geothermal processes. With reference to lake bottoms, the degradation can occur inside the lake or fluids derived from similar processes can be fed from outside.

Carbon dioxide can also be considered as the product of decay of organic matter, but significant increases in its concentrations with depth, without corresponding increases in ammonium, appear better justified by contributions of fluids from an external source. At Averno, where only ammonium anomalies are detected in the deep sample, a degradation of organic material occurring inside the lake appears as a sufficient explanation; at Monoun, Nyos, and Albano, some extent of fluid contribution from outside seems to fit the chemical composition better.

Figures 5, 6, and 7 show vertical profiles of temperature, $\mathrm{pH}$, and dissolved $\mathrm{CO}_{2}$ for the Italian lakes. The $\mathrm{B}$ and $\mathrm{Li}$ concentrations in these lakes appear as related to thermal anomalies, but the constant patterns for temperature values at depth allows to rule out important thermal anomalies near the lake bottoms, as observed at Lakes Nyos and Monoun (Kusakabe and Sano, 1992). A similar homogeneity can be derived also for $\mathrm{pH}$ values and dissolved $\mathrm{CO}_{2}$, with the exception of Lake Albano.

In addition to chemical evidences, the morphology of crater lakes in areas of recent and quiescent volcanism can provide information about residual phenomena associated to past activities. A detailed investigation by means of Video Scan Sounder revealed the shapes of the ancient craters where the Italian lakes are hosted (Figs. 8-10).

Besides minor particulars, Lakes Bolsena, Vico, Bracciano, Martignano, Nemi, and Averno, appear as characterized by substantially flat bottoms, possibly produced by continuous sedimentary refilling, while a funnel shape pertains to Lake Albano. A quiet sedimentation can be thus regarded as a normal stage for most of the lakes considered; at Albano, on the contrary, a "cleaning" by circulating fluids can be inferred. 


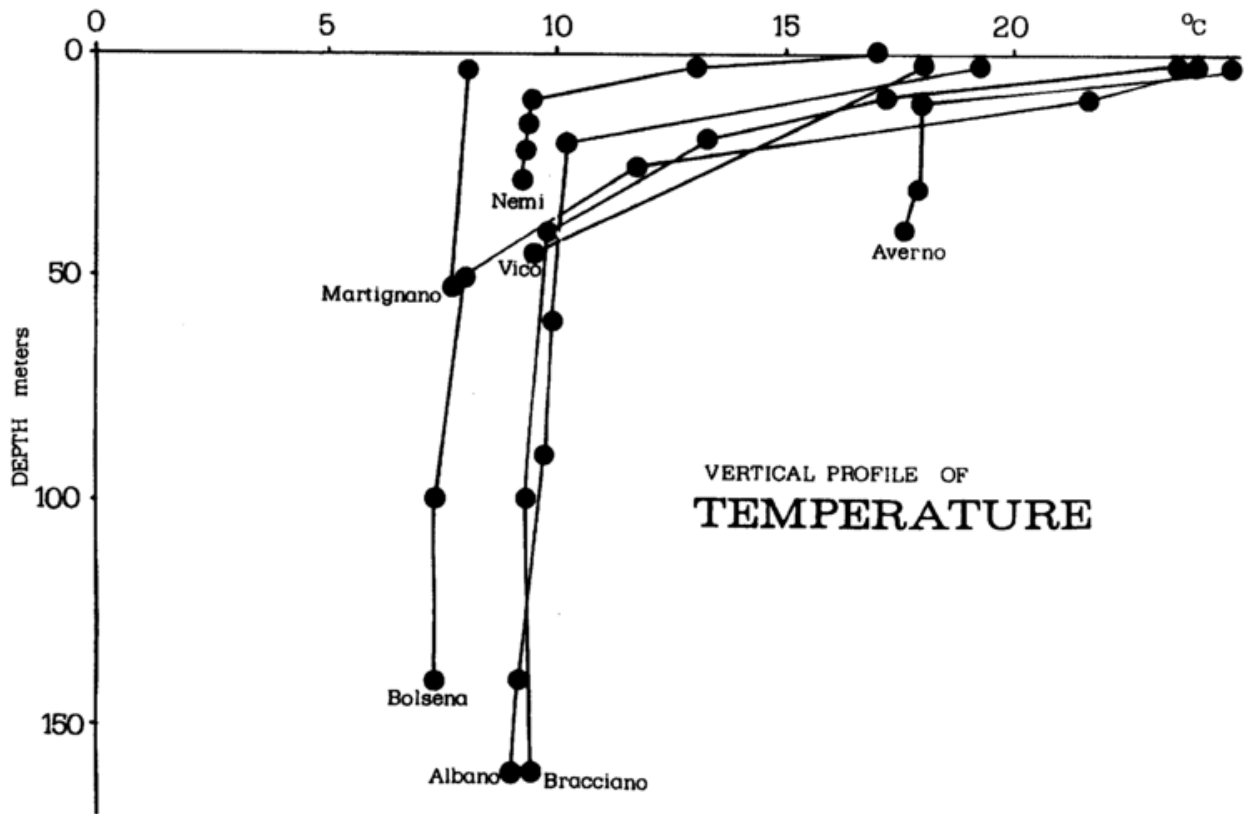

Fig. 5. Bathymetric profile of temperatures for Italian lakes.

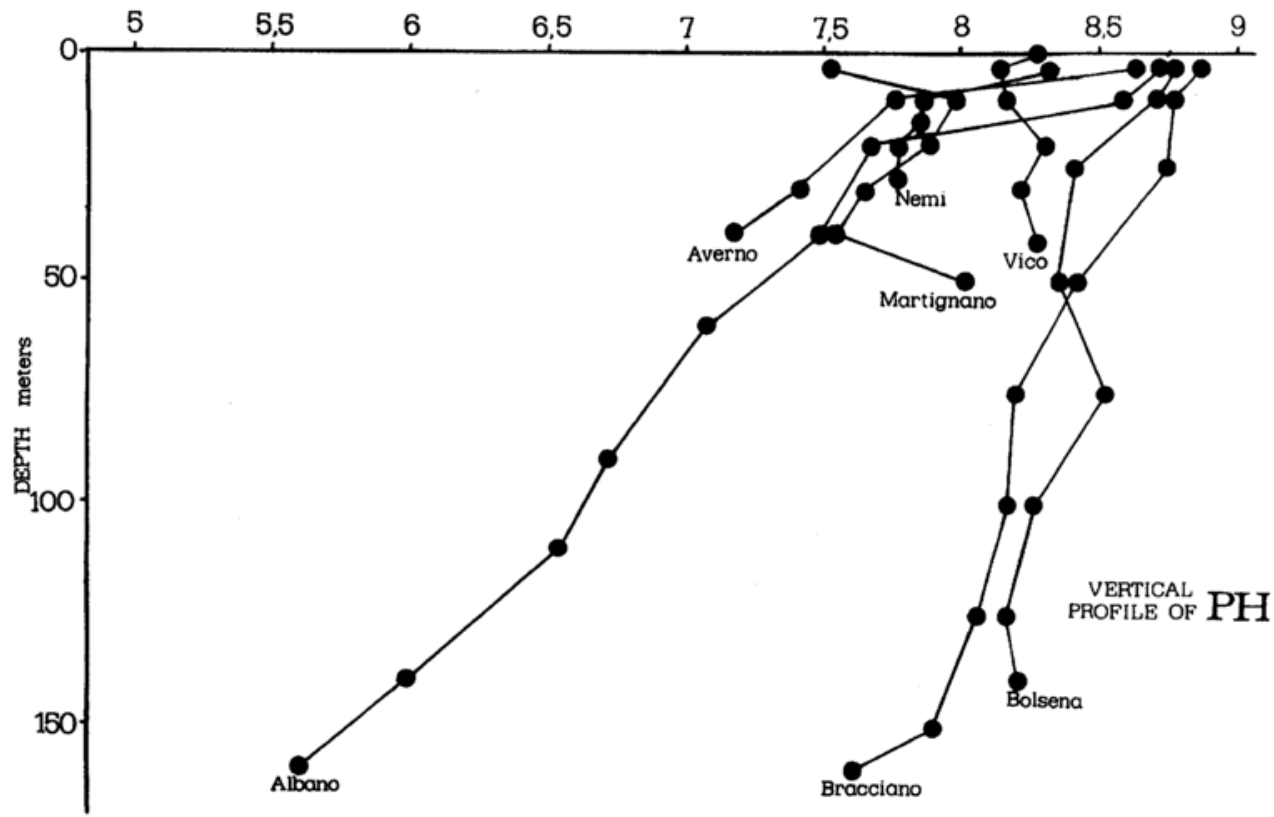

Fig. 6. Bathymetric profile of pH-values of Italian lakes. 


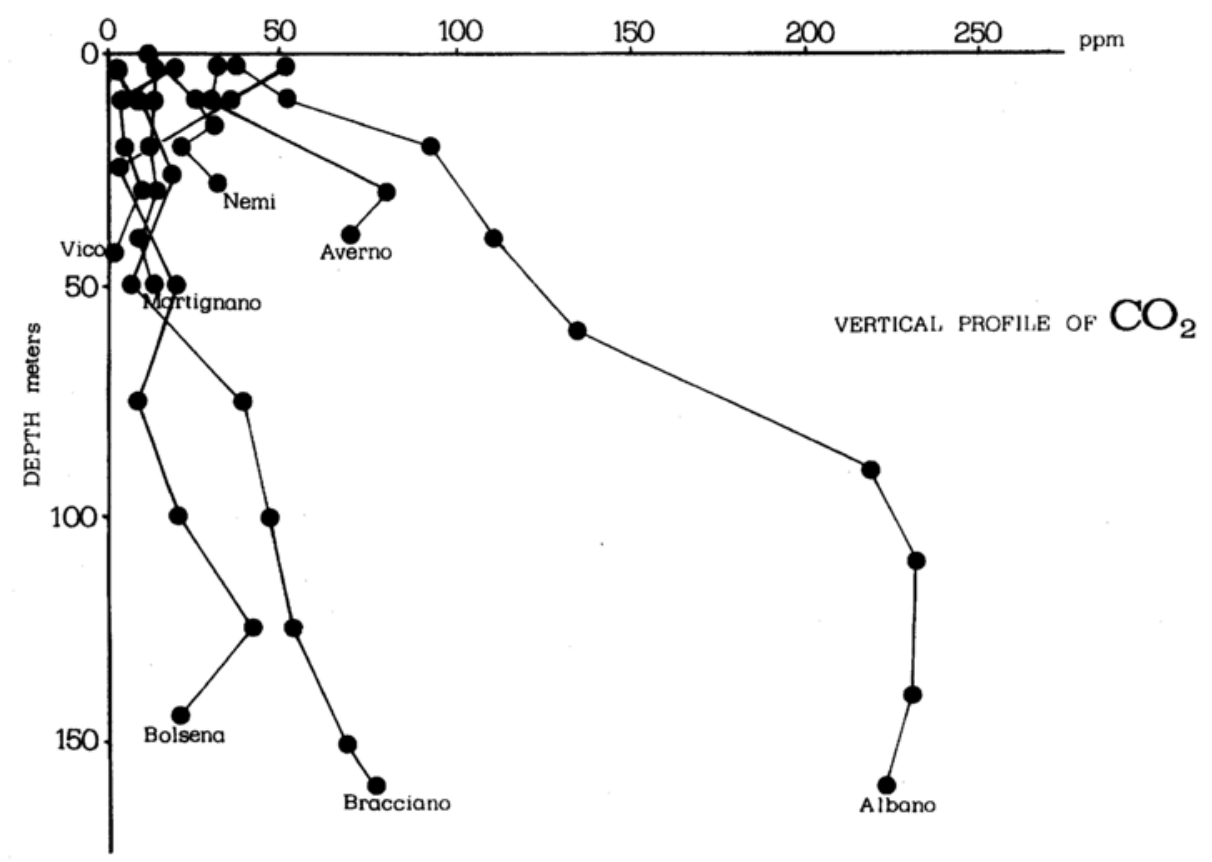

Fig. 7. Bathymetric profiles of dissolved $\mathrm{CO}_{2}$ for Italian lakes.

BOLSENA LAKE MAXIMUM DEPTH $186 \mathrm{M}$.

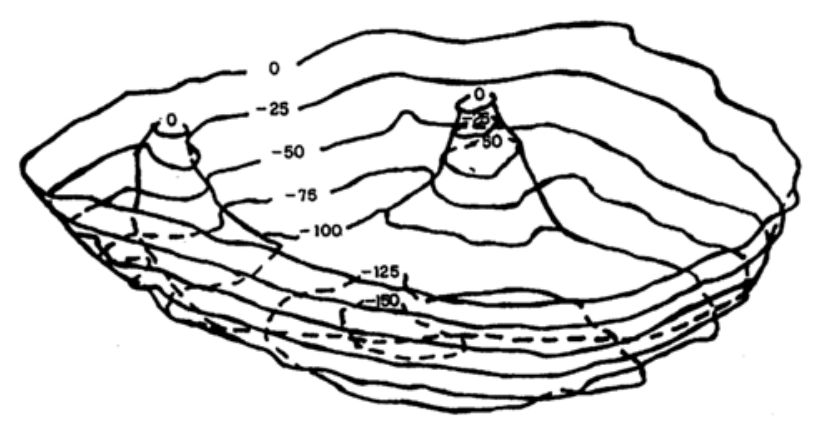

Exaggerated vertical scales
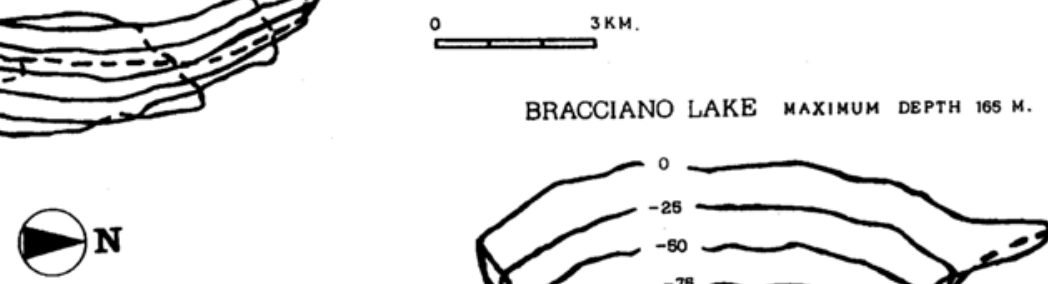

BRACCIANO LAKE MAXIMUM DEPTH $165 \mathrm{M}$.

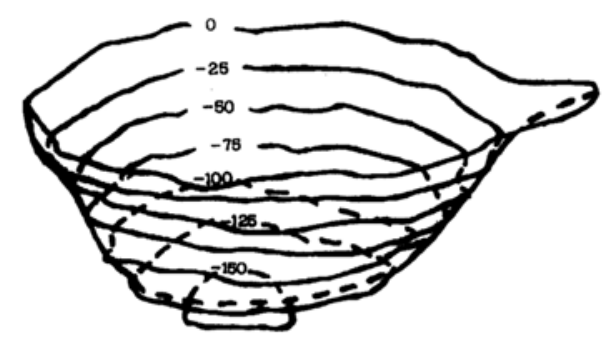

Fig. 8. Reconstruction of the shapes of Bolsena and Bracciano lakes. 

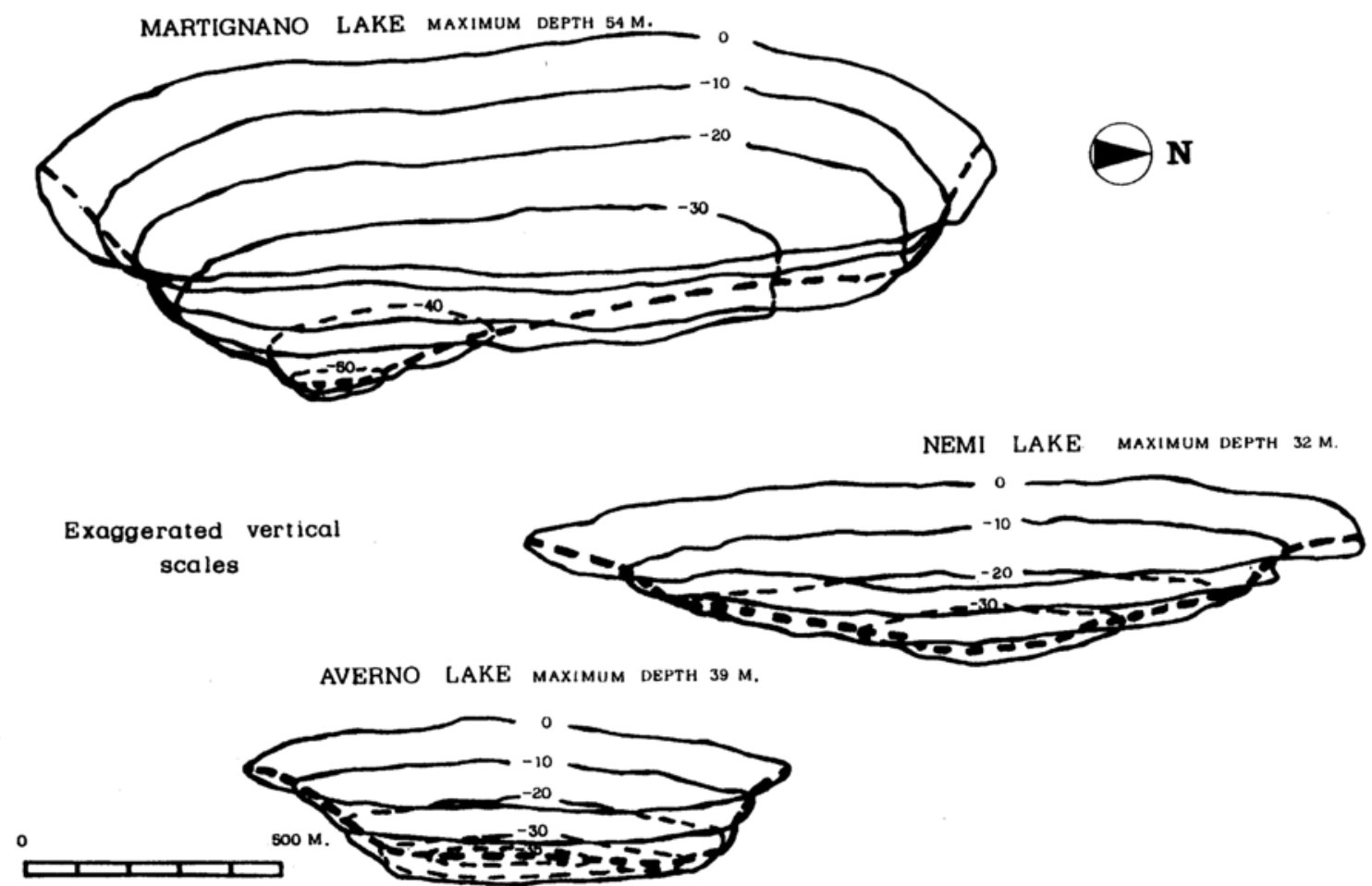

Fig. 9. Reconstruction of the shapes of Martignano, Nemi, and Averno lakes.

ALBANO LAKE MAXIMUM DEPTH $177 \mathrm{M}$.

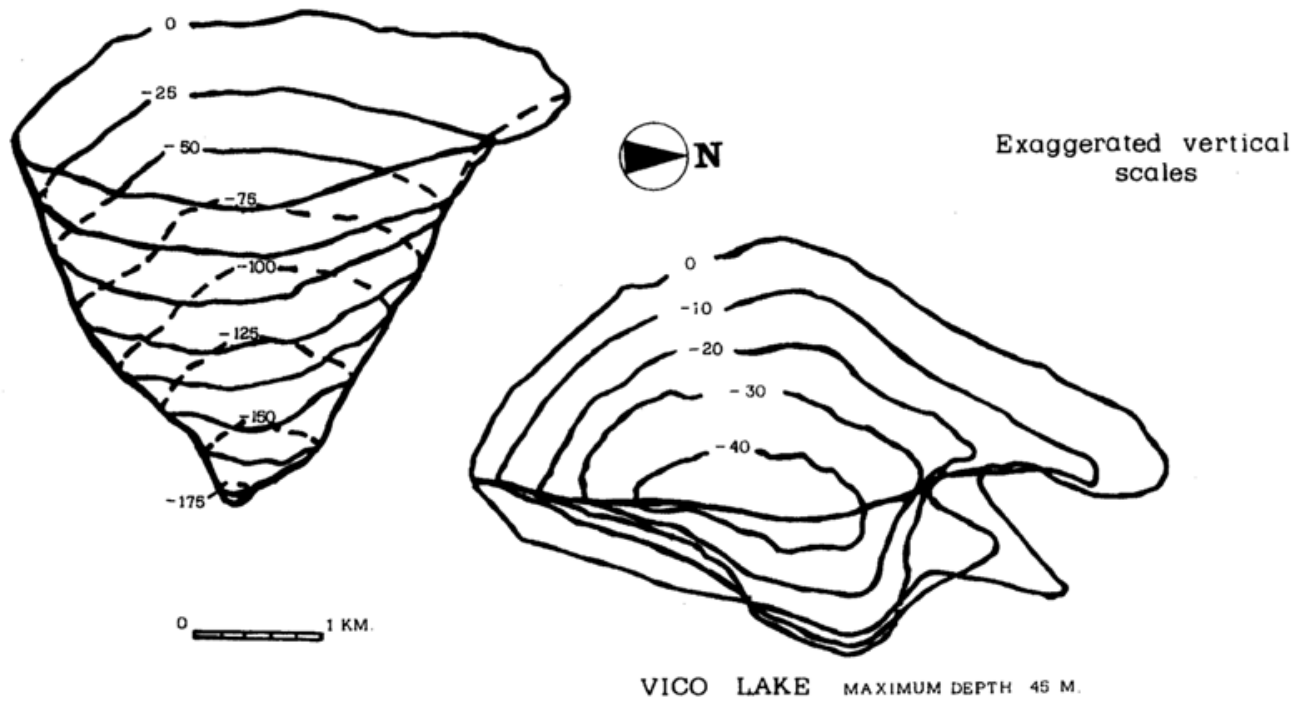

Fig. 10. Reconstruction of the shapes of Albano and Vico lakes. 


\section{CONCLUSIONS}

According to the data collected during this investigation, in comparison with observations carried out at Cameroonian crater lakes, the variations with depth of temperature, $\mathrm{pH}$, and chemical composition provide useful information about the persistence of anomalies possibly connected to past activities of the volcanic systems. Among chemical components, carbon dioxide and ammonium seem to reflect the contribution of endogene fluids to a greater extent.

From these data, besides Lakes Monoun and Nyos for which convincing evidence is available, some kind of the above mentioned anomalies can be inferred for Lake Albano. The reconstruction of the shapes, carried out for the Italian lakes, appears again to differentiate Albano with respect to the other systems. These differences cannot allow a sufficient evidence of residual phenomena associated to past volcanic activity; information from historical records, however, seems to provide further hints about.

Titus Livius, whose "Ab Urbe Condita Libri CXLII" represent the most important source of Roman history during the first eight centuries, reports the following: "Many wonders happened ... one in particular caught people's attention; the rising level of the waters of Lake Albano, not because of rainfall or of any other natural reason ... the water flooded out of the lake ...". These events occurred in the year 364 of Roman calendar, corresponding to 390 b.C., cannot be interpreted in a simple way; some instability, however, appears to have characterized Lake Albano at that time and an emission of fluids at depth may have been responsible.

On the basis of the information about physicochemical characters of crater lakes, it appears thus possible to distinguish areas for which residual influences of the volcanic systems can be hypothesized; some even minor degree of hazard because of potential instabilities can be estimated accordingly.

Acknowledgments - We thank Prof. V. H. Forjaz of Universidade dos Azores for the assistance in collect- ing samples in the Azores. This work was financially supported by Gruppo Nazionale di Vulcanologia and C.N.R. Centro di Studio per la Minerogenesi e la Geochimica Applicata.

\section{REFERENCES}

Barberi, F., Chelini, W., Marinelli, G. and Martini, M. (1989) The gas cloud of Lake Nyos (Cameroon, 1986): results of the Italian technical mission. $J$. Volcanol. Geoth. Res. 39, 125-134.

Bertagnini, A. and Sbrana, A. (1986) Il vulcano di Vico; stratigrafia del complesso vulcanico e sequenze eruttive delle formazioni piroclastiche. Mem. Soc. Geol. It. 35, 699-713.

Booth, B., Croasdale, R. and Walker, G. P. L. (1983) Volcanic Hazard on San Miguel, Azores. Forecasting Volcanic Events (Tazieff, H. and Sabroux, J. C., eds.), Elsevier, Amsterdam.

Casadevall, T. J., De la Cruz-Reyna, S., Rose, W. I., Bagley, S., Finnegan, D. L. and Zoller, W. H. (1984) Crater lake and post-eruption hydrothermal activity, El Chichòn volcano, Mexico. J. Volcanol. Geoth. Res. 23, 169-191.

Casertano, L., Borgia, A., Cigolini, C., Morale, L. D., Montero, W., Gomez, M. and Fernandez, J. F. (1985) Investigaciones geofìsicas y caracterìsticas geoquimicas de las aguas hidrotermales: Volcan Poas, Costa Rica. Geofis. Intern. 24, 315-322.

De Rita, D., Funiciello, R. and Rosa, C. (1991) Volcanic activity and drainage network evolution of the Alban Hills area (Rome, Italy). Acta Vulcanologica 2, 185-198.

Giggenbach, W. F. (1974) The chemistry of Crater Lake, Mt. Ruapehu (New Zealand) during and after the 1971 active period. N.Z. J. Sci. 17, 33-45.

Gillot, P. Y., Nappi, G., Santi, P. and Renzulli, A. (1991) Space-time evolution of the Vulsini Volcanic Complexes, Central Italy. EUG VI, Strasbourg, Earth Abs., 3-1, 445.

Kusakabe, M., Ohsumi, T. and Aramaki, S. (1989) The lake Nyos disaster: chemical and isotopic evidence in waters and dissolved gases from three Cameroonian crater lakes, Nyos, Monoun, and Wum. J. Volcanol. Geoth. Res. 39, 167-185.

Kusakabe, M. and Sano, Y. (1992) The origin of gases in Lake Nyos, Cameroon. Natural Hazards in West and Central Africa (Freeth, S. J., Ofoegbu, C. O. and Onuoha, K. M., eds.), Vieweg, Wiesbaden.

Locardi, E. (1965) Tipi di ignimbriti di magmi mediterranei. Le ignimbriti del vulcano di Vico. Atti Soc. Tosc. Sci. Nat. 72, 55-173.

Machado, F., Parsons, W. H., Richards, A. F. and Mulford, J. W. (1962) Capelinhos eruption of Fayal 
Volcano, Azores, 1957-58. J. Geophys. Res. 67, 3519-3529.

Martini, M., Cellini Legittimo, P., Piccardi, G. and Giannini, L. (1984) Low temperature manifestations in volcanic areas. Rend. Soc. It. Min. Petr. 39 401405.

Nappi, G., Renzulli, A. and Santi, P. (1991) Evidence of incremental growth in the Vulsinean calderes (Central Italy). J. Volcanol. Geotherm. Res. 47, 1331.

Ossaka, J., Ozawa, T., Nomura, T., Ossaka, T., Hirabayashi, J., Takaesu, A. and Hayashi, T. (1980) Variation of chemical compositions in volcanic gases and waters at Kusatsu-Shirane volcano. Bull. Volcanol. 43, 207-216.
Rosi, M., Sbrana, A. and Principe, C. (1983) The Phlegrean Fields: structural evolution, volcanic history and mechanism. J. Volcanol. Geoth. Res. 17, 273-288.

Sigurdsson, H., Devine, J. D., Tchoua, F. M., Presser, T. S., Pringle, M. K. W. and Evans, W. C. (1987) Origin of the lethal gas burst from lake Monoun, Cameroon. J. Volcanol. Geoth. Res. 31, 1-16.

Sigvaldason, G. (1989) The lake Nyos event and natural $\mathrm{CO}_{2}$ degassing. J. Volcanol. Geoth. Res. 39, 109-116.

Turbeville, B. N. (1993) Petrology and petrogenesis of the Latera caldera, Central Italy. J. Petrology 34, 77123.

Varekamp, J. C. (1980) The geology of the Vulsinian area, Lazio, Italy. Bull. Volcanol. 43, 487-503. 